\title{
DECISION MAKING ON WEB PROJECT MANAGEMENT UNDER UNCERTAINTY
}

\author{
Cheverda S.S., Mishchenko A.O. \\ Zaporizhzhia National University \\ Ukraine, 69600, Zaporizhzhia, Zhukovsky str., 66 \\ cheverdaserega@gmail.com, anna.mainery@gmail.com \\ ORCID: 0000-0002-0473-7195
}

Key words:

web project, project management, data uncertainty, project decision making, fuzzy data, fuzzy logic.
The relevance of the article is due to the fact that the methods and tools used for web project management today do not take into account: the impact of human factors on project management processes and its implementation at all stages of the web project life cycle and the presence of uncertainties in data used in adoption design solutions for web project management. Describes the methods and procedures for the formation of project solutions in the management of web projects in the case of incompleteness and inaccuracy of some characteristics of the project. The main factors of project decision-making are analyzed, the causes and nature of incompleteness and inaccuracy of design characteristics are determined, in connection with which the concept of uncertainty was introduced, the most common types of uncertainties that arise when managing web projects are described. The main ways to solve the problem of web project management taking into account the absence, incompleteness and / or inaccuracy of project data, each of which can be implemented by three methods. To solve this problem, an approach to the application of project specifications has been developed, which creates opportunities for their proper use in project management processes, reducing risks and ensuring the efficiency, quality and reliability of solutions. Procedures for reducing the level of incompleteness and inaccuracy of project characteristics based on fuzzy logic, the use of which involves the replacement of quantitative values by ambiguous linguistic estimates, which reflect the semantics of such estimates and the relationship between values, allowing the transition from absolute values to relative estimates in project decisions, as well as to eliminate the incompleteness and inaccuracy of the values of the calculated characteristics, to form a homogeneous system of measuring various decision-making factors for the web project. The proposed approach makes it possible to create tools for dealing with uncertainty and create a decision-making system for managing web projects.

\section{ПРИЙНЯТТЯ РІШЕНЬ 3 УПРАВЛІННЯ ВЕБ-ПРОСКТАМИ В УМОВАХ НЕВИЗНАЧЕНОСТІ}

\author{
Чеверда С.С., Міщенко А.О. \\ Запорізький національний університет \\ Україна, 69600, м. Запоріжжя, вул. Жуковського, 66
}

\author{
Ключові слова: \\ веб-проєкт, управління \\ проєктами, невизначеність \\ даних, прийняття проєктних \\ рішень, нечіткі дані, \\ нечітка логіка.
}

Актуальність статті зумовлена тим, що методи та засоби, які застосовуються для управління веб-проєктами, сьогодні не враховують: вплив людського чинника на процеси управління проєктом і його реалізацію на всіх стадіях життєвого циклу веб-проєкту та наявність невизначеностей у даних, які використовуються при прийнятті проєктних рішень з управління веб-проєктом. Описано способи та процедури формування проєктних рішень в управлінні веб-проєктами за умови неповноти та неточності деяких характеристик проєкту. Проаналізовано основні чинники прийняття проєктних рішень, визначено причини та природу виникнення неповноти і неточності проєктних характеристик, у зв'язку з чим було введено поняття невизначеності, описано найпоширеніші типи невизначеностний, які виникають при управлінні веб-проєктами. Розглянуто основні шляхи вирішення проблеми управління веб-проєктами з урахуванням відсутності, неповноти та/або неточності даних проєкту, кожен з яких можливо реалізувати трьома методами. Для вирішення цієї проблеми розроблено підхід застосування проєктних специфікацій, який створює можливості для їх належного використання у процесах управління проєктами, зменшуючи ризики та забезпечуючи ефективність, якість і надійність рішень. Визначено процедури зменшення рівня неповноти та неточності характеристик проєкту на основі нечіткої логіки, використання якої передбачає заміну кількісних значень неоднозначними лінгвістич- 
ними оцінками, які відображають семантику таких оцінок та взаємозв'язок між значеннями, що дозволяє перехід від системи абсолютних величин до відносних оцінок при прийнятті проєктних рішень, а також виключити неповноту та неточність значень розрахункових характеристик, сформувати однорідну систему вимірювання різних факторів прийняття рішення щодо веб-проєкту. Запропонований підхід дає можливість створити засоби опрацювання невизначеності і створити систему прийняття рішень для управління веб-проєктами.

\section{Statement of the problem}

The current stage of development of projects, the result of which is a product that operates on the World Wide Web, is characterized by the urgent need to make optimal decisions as quickly as possible and increase the efficiency of operation in a highly competitive environment. Unlike the previous stage of the initial attempts to do business on the World Wide Web, when the main task was the transition of business from traditional verbal to innovative interactive methods, now more important are the tasks of rapid growth and involvement of your market share in the Internet. To ensure the necessary speed and quality of decision-making on web project management is possible through the development of new methods of taking into account the uncertainty in making management decisions by the project manager.

Modern web project management technologies represent such developments as TeamBridge service, IPI.Manager, Redmine, Primavera Project Planner etc. Structures of Project Management Institute Inc., OASIS, ISO, ANSI, Google, Microsoft and IBM are actively developing the latest standards and methods of web project management. This indicates that the research issues in the field of improving the methods and tools of web project management are relevant both in terms of theory and in practice. However, it should be noted, that methods and tools for web product management today do not take into account some factors. Such as: the impact of the human factor on project management process and its implementation at all stages of the web project life cycle and identify uncertainties in the data used in decision making on web project management.

\section{Analysis of recent studies and publications}

The issue of creation, implementation and application of Internet technologies for management decisions today is quite relevant. Fundamental issues of web project management are considered in $[1,2,3]$. In [1] describes the general structure, principles of organization, and the order of design, creation and application of e-commerce system. The main purpose of such web systems is to distribute information technology products on a commercial basis [1]. In works $[2,3]$ theoretical researches are carried out and the basic principles of functioning of systems are substantiated, ways of formation of information streams and their management are described.

\section{Objectives of the article}

The aim of this work is to build an algorithm for processing the uncertainty of project characteristics when making decisions about web project management.

\section{The main material of the research}

When making management decisions during the implementation of a web project often have to process, interpret and use unknown and inaccurate data [4]. There are main reasons for creating such problematic situations:

- complete or temporary absence of some values;

- lack of data due to confidentiality or competition;

- unreliability of the received data and sources of their reception;

- significant inaccuracies and errors in values due to shortcomings in their formation;

- subjectivity of assessments and assertion;

- discrepancies in data obtained from different sources;

- deviations in the time of formation and use of certain values;

- unwillingness of the organization or person to provide the necessary information.

In cases where the project executor does not have the necessary set of accurate and reliable data, decision-making processes for planning the implementation of a web project, the formation of project resources, the organization of their implementation are much more complicated or impossible [5]. As a result, it can lead to violation of project plans, delays, changes in the content, cost or quality of the project or complete abandonment of its implementation. There are main ways to solve the problem of web project management in the context of incomplete and inaccurate project data:

- implementation of measures to fill in and adjust the project data required for project implementation;

- performing special actions to reduce the level of incomplete and inaccuracy of data through their analysis, replacement of and conversion;

- organization of project decision-making and project implementation taking into account the absence, incompleteness and / or inaccuracy of some project indicators.

Each of these measures has a certain effect, but it cannot completely solve the problem of incompleteness and inaccuracy of project data. In the first case, obtaining a complete and reliable set of values requires additional steps, which accordingly require additional time and resources. At the same time, there is no absolute guarantee of complete elimination of the problem in the separately taken and general case. The second method allows you to replace lost or inaccurate values with other values that can be used instead with the appropriate level of reliability. The third method involves changing the design decisionmaking process, taking into account the fact that the values of some design features are replaced by the values of substitution obtained as a result of some transformations and replacements. 
Thus, it can be concluded that the solution to the problem of making decisions about web project management in case of incompleteness and inaccuracy of certain project data is to develop an approach that combines the proposed solutions in three ways. This way of applying project specifications will create opportunities for their proper use in network project management processes, reducing risks and ensuring the efficiency, quality and reliability of solutions.

Introduce the concept of uncertainty, which means inaccuracy or incompleteness, absence or instability of data on a particular web project and its participants. There are the most common types of uncertainty according to [6] following:

- incorrect value (costs for this object are unacceptable due to its nature or other objective or subjective reasons);

- value unknown (this type of uncertainty implies possibilities - the value exists but is not established or the very fact of its existence has not been proven);

- value does not exist (this means that it cannot be formed for objective reasons or is not currently formed. The algorithm should be adjusted so that without this value it is possible to form a project management strategy. If the parameter with this type of uncertainty is decisive for the decision-making, you should use the average, approximate or expert judgment);

- value cannot be determined (this type of uncertainty assumes the existence of the value itself and its unavailability for use);

- the value is invalid (such uncertainty arises due to the unreliability of information sources, obtaining different data from several sources, the use of anonymous sources, uncertainty in estimates, inaccuracies and measurement errors. In this case, it is necessary to determine whether the wrong value was accidentally obtained, whether the client intentionally provided incorrect information and this can be corrected);

- the value was not obtained (in this case, the existing value is assumed to be reliable, but for some reason was not taken (or not accepted temporarily) in the order of its application. This type of ambiguity can be explained by re-searching for the required value);

- values are represented by an empty set (uncertainties of this kind arise in relation to total quantities, for example, the list of the company's customers, units sold, the list of previous employee positions).

One set of these indicators is enough to make typical decisions. Analysis of these indicators shows that determining their exact values in practice is quite a difficult task, sometimes even impossible. The fact that the web project in its properties meets the requirements of the method of situational analysis, allows you to organize the management decision-making process on the basis of incomplete, inaccurate or incomprehensible values without losing the efficiency and quality of the end result. This allows you to replace the values of the parameters monitored by the web project with some general values that allow you to make decisions during the implementation of the web project and evaluate the results of related changes.

To the characteristics of the parameters that determine the properties of the web project, we can add the lack of formal methods and procedures for setting values for many of them. This approach allows the application of the principles of fuzzy logic to these features of the project [7], according to which the evaluation results are presented in the form of verbal language, and management is not based on real values, but on their ambiguous counterparts.

The application of fuzzy logic to processes and control systems means working according to the scheme: clear meaning $\rightarrow$ definition of affiliation function $\rightarrow$ fassification (transition to fuzzy) $\rightarrow$ fuzzy calculations $\rightarrow$ defassification (transition to exact values). The characteristics of a web project and the use of situation management models to create project management technology require the use of another method of forming and implementing fuzzy parameter values in management processes. The first step is the direct formation of an expert verbal assessment of $h_{i}^{*}, i=1$, Num $^{\text {PrChar }}$ value of the i-th control parameter without determining its exact value.

In terms of presentation and interpretation, vague estimates of different parameters differ. To share processes and tools for managing web projects, the next step is to normalize them - reducing the various ambiguous parameter values to a single syntax and interpretation.

Rationing is carried out by semantic differentiation [8] using a special scale. This action involves the replacement of the verbal $h_{i}^{*}, i=1, N_{u m}{ }^{\text {PrChar }}$ by the numerical value $d_{i}^{*}, i=1$, Num $^{\text {PrCha }}$, taking into account the content and relationship between language values. In this case, the numerical values do not specify any quantitative concepts, but only formalize the relevant ambiguous verbal assessments and the relationship between them. It is quite convenient to use the degree of semantic differentiation in the range of numerical values $[0 ; 1]$.

Options for determining ambiguous linguistic estimates for those project indicators that allow such an assessment and their normalized values are given in Tab. 1.

Usually, for project decisions on web project management, it is not the value of a certain feature of the project that is important, but its relative assessment [9]. The absolute value of the indicator depends on the characteristics of each project, and different projects may have different interpretations.

For example, a project budget is too small for a corporate client, too large for an individual, and vice versa. Accordingly, the inaccuracy or incompleteness of some design features can be eliminated or reduced by moving from absolute to relative values. The most acceptable for this is the use of fuzzy logic L. Zadeh [10]. The use of this tool involves the replacement of quantitative values by ambiguous linguistic estimates that reflect the semantics of such estimates and the relationship between values.

To determine the correspondence between "true" and "false", you must first define the affiliation function. This process is called fassification [10]. Applying this process when processing a set of values for the characteristics of creating a web project as a separate category of IT projects, you can achieve the following goals:

- transition from the system of absolute values to relative estimates when making project decisions;

- to exclude incompleteness and inaccuracy of values of calculated characteristics; 
Tab. 1 - Linguistic assessments of project indicators

\begin{tabular}{|c|c|c|c|}
\hline Parameter & The content of the parameter & Linguistic meanings & $\begin{array}{l}\text { Normalized } \\
\text { value }\end{array}$ \\
\hline \multirow{3}{*}{$h_{C F i n_{C} \_I n c}{ }^{*}$} & \multirow{3}{*}{ The level of the client's income } & High & 1 \\
\hline & & Middle & 0,5 \\
\hline & & Low & 0 \\
\hline \multirow{3}{*}{$h_{\text {CPers_CGender }}{ }^{*}$} & \multirow{3}{*}{ Gender of the customer's representative } & More priority & 1 \\
\hline & & Irrelevant & 0,5 \\
\hline & & Less priority & 0 \\
\hline \multirow{5}{*}{$h_{\text {CPers_cLang }}^{*}$} & \multirow{5}{*}{ The language of communication } & Fluency & 1 \\
\hline & & Above the average & 0,75 \\
\hline & & Middle level & 0,5 \\
\hline & & Below the average & 0,25 \\
\hline & & Does not have the skills & 0 \\
\hline \multirow{3}{*}{$h_{\text {CPers_cProf }}{ }^{*}$} & \multirow{3}{*}{$\begin{array}{l}\text { Professionalism of the customer's } \\
\text { representative }\end{array}$} & Professional & 1 \\
\hline & & Middle level & 0,5 \\
\hline & & Does not have the skills & 0 \\
\hline \multirow{3}{*}{$h_{\text {PFin } p \text { BFlex }}^{*}$} & \multirow{3}{*}{ Budget flexibility } & The budget is flexible, expandable & 1 \\
\hline & & Expandable in critical cases & 0,5 \\
\hline & & Inflexible & 0 \\
\hline \multirow{3}{*}{$h_{\text {DCRel_cRelPeriod }}{ }^{*}$} & \multirow{3}{*}{ Frequency of relations with the client } & $\begin{array}{l}\text { Periodic, relationship termination } \\
\text { is not planned }\end{array}$ & 1 \\
\hline & & $\begin{array}{l}\text { Periodic, but with predicted endings } \\
\text { of the relationship }\end{array}$ & 0,5 \\
\hline & & One-time project & 0 \\
\hline \multirow{3}{*}{$h_{\text {DCRel_cPrior }}^{*}$} & \multirow{3}{*}{$\begin{array}{l}\text { Customer priority } \\
\text { for the performer }\end{array}$} & Maximum & 1 \\
\hline & & Middle & 0,5 \\
\hline & & Minimum & 1 \\
\hline \multirow{3}{*}{$h_{\text {COrg_cOwn }}^{*}$} & \multirow{3}{*}{ Form of ownership of the client } & Priority for the performer & 1 \\
\hline & & Does not matter & 0,5 \\
\hline & & Non-priority & 0 \\
\hline \multirow{3}{*}{$h_{\text {COrg_cArea }} *$} & \multirow{3}{*}{ Customer's field of activity } & $\begin{array}{l}\text { Priority and interesting } \\
\text { for the performer }\end{array}$ & 1 \\
\hline & & Does not matter & 0,5 \\
\hline & & Non-priority & 0 \\
\hline \multirow{3}{*}{$h_{\text {PReq } p U r g}^{*}$} & \multirow{3}{*}{ Urgency of the project } & High & 1 \\
\hline & & Middle & 0,5 \\
\hline & & The project is not urgent & 0 \\
\hline
\end{tabular}

- to form a homogeneous system of measuring various decision-making factors for web projecting.

To ensure the uniformity of data in the design decisionmaking process, it is desirable to further standardize them and reduce them to a single format and measurement system. This can be achieved by moving from significant linguistic values to numerical values that support the relationship of unclear estimates. The method of bipolar graduated scales (by Ch. Osgood [8]), built on the principle of semantic differentiation, is the most suitable for this purpose.

This method involves creating a correspondence between linguistic semantic meanings and several ordered groups of numbers - scales. This commonality is formed in a special way, reflecting the ratio of the content of unclear estimates through the ratio of the numbers. There are basic principles of constructing the Osgood scale [8]:

- the presence of extreme polar values - minimum and maximum; point;
- number of elements for calibration of the scale from 3 (minimum) to 7 (maximum).

Using bipolar scales to represent the values of web project features allows you to solve the following problems:

- create a unique homogeneous system for the presentation and measurement of all design features;

- provide the ratio of the values of the calculated characteristics in the form of numerical ratios;

- compare the values of design features with different content;

- apply formal methods and decision-making in the management of web projects in conditions of uncertainty.

In order to reduce the level of uncertainty of project features in decision-making processes, certain steps should be taken.

The set of values of the characteristics of the web project is divided into the following categories:

\footnotetext{
- existent and accurate;

- existent inaccurate;

- missing.
} 
If there are no values, you should state the reasons for the lack of values for the characteristics of the web project according to the list above.

As a result, if it is determined that the value is absent due to its inadmissibility or lack of conditions for its occurrence, then:

- it cannot be decided that this feature belongs to the category of key factors;

- decision-making, when this feature of the project is a secondary factor, is carried out without taking into account the lack of influence of this factor on decision-making.

If the reason for the lack of value of the project feature is its unavailability, non-acceptance or unreliability in the design decision-making process, it will be replaced by the equivalent replacement in the following options:

- use the predictable (calculated) value;

- use the average value of this indicator;

- use the most plausible assumption about its value.

As a result of such steps the full set of exact numerical values of characteristics of the project necessary for acceptance of the design decisions reduced to one scale of estimation is developed:

$$
\begin{gathered}
h^{*}=\left\{h_{1}^{*}, h_{2}{ }^{*}, \ldots, h_{\text {Num }{ }^{*} \text { PrChar }}^{*}\right\}, h^{*}=<\text { Name } h_{j}, \\
\text { NumValue } h_{j}>,
\end{gathered}
$$

where Num $^{*}{ }^{\text {PrChar }}$ - is the number of web project characteristics that are used when making project management decisions after reducing data uncertainty.

Name $-h-$ is the name of the project characteristic, NumValue $h_{j}{ }_{*}$ - its numerical relative value, NumValue_ $h_{j} \in \bar{S} c\left(h_{j}{ }^{*}\right), S c\left(h_{j}\right)-$ is the scale of fuzzy linguistic meanings $\mathrm{j}$-th project characteristics, $j=1,2, \ldots, \mathrm{Num}_{*}{ }^{\mathrm{Pr} C h a r}$

Therefore, the initial decision-making model for the implementation of a web project $s_{i}\left(h_{1}, h_{2}, \ldots, h_{N^{*} \text { PrChar }}\right)$ can be changed to the following::

$$
Q_{i}^{*}: S c^{*}\left(h_{1}{ }^{*}\right) \cdot S c^{*}\left(h_{2}{ }^{*}\right) \cdot \ldots \cdot \operatorname{Sc}^{*}\left(h^{*}{ }_{\text {Num }}^{*} \operatorname{PrChar}{ }^{*}\right) \rightarrow \operatorname{Dom}\left(s_{j}\right),
$$

where $S c *\left(h_{1}\right) \cdot S c *\left(h_{2}\right) \cdot \ldots \cdot S c *\left(\begin{array}{ll}h_{\text {Num }}^{*} \text { PrChar } \\ \end{array}\right)-$ is generalized Cartesian product of numerical scales of fuzzy linguistic values of web project features. $\operatorname{Dom}(s)-$ is a set of possible values of design decisions $s_{i}$.

Tab. 2 describes the possibility of implementing ways to reduce uncertainty in the values of the characteristics of the web project without losing the exact result or with little loss. Here is an example: if the value of the scale of a web project is uncertain, the following method as an expert assessment is likely to give an inaccurate and incorrect result, as this indicator can be attributed to difficult-to-predict indicators.

The issue of choosing a web project management strategy and management decisions under uncertainty can be divided into two stages: processing uncertainties in project indicators and choosing a web project management strategy based on previously obtained project indicators.

The algorithm for processing the listed uncertainties consists of a sequence of actions, the result of which is the creation of a number of project characteristics that are factors for management decisions:

a) a) identify elements of the web project that have an impact on the choice of management strategy (values are formed in the process of interaction between the client,

\begin{tabular}{|c|c|c|c|c|c|c|}
\hline $\begin{array}{l}\text { The name of the project } \\
\text { characteristic }\end{array}$ & Expectation & $\begin{array}{l}\text { Repeat } \\
\text { request }\end{array}$ & $\begin{array}{l}\text { Average } \\
\text { value }\end{array}$ & $\begin{array}{c}\text { Expert } \\
\text { evaluation }\end{array}$ & Extrapolation & $\begin{array}{l}\text { Replacement } \\
\text { inaccurate }\end{array}$ \\
\hline Customer income & + & + & - & + & - & + \\
\hline $\begin{array}{l}\text { Preliminary income of the performer } \\
\text { from the client }\end{array}$ & + & + & - & + & + & + \\
\hline Potential income from the client & + & + & - & + & + & + \\
\hline $\begin{array}{c}\text { Characteristics of the client's } \\
\text { representatives }\end{array}$ & + & + & + & - & - & - \\
\hline The language of communication & + & + & - & + & - & + \\
\hline $\begin{array}{c}\text { Professionalism of the client's } \\
\text { representatives }\end{array}$ & + & + & + & + & - & + \\
\hline $\begin{array}{c}\text { Number of people making project } \\
\text { decisions }\end{array}$ & + & + & + & - & - & - \\
\hline The scale of the project & + & + & - & - & - & + \\
\hline Budget flexibility & + & + & - & - & - & + \\
\hline Ways of financing & + & + & - & - & + & + \\
\hline Importance for the performer & + & + & + & + & + & + \\
\hline $\begin{array}{c}\text { Frequency of communication } \\
\text { with the client }\end{array}$ & + & + & + & - & - & + \\
\hline Comfort of work with the customer & + & + & + & + & - & + \\
\hline Customer priority & + & + & + & - & - & + \\
\hline Form of ownership of the customer & + & + & - & + & - & - \\
\hline Customer's field of activity & + & + & - & - & - & - \\
\hline Urgency & + & + & + & - & - & - \\
\hline Project technologies & + & + & - & - & - & - \\
\hline
\end{tabular}
manager and other project participants);

Tab. 2 - Ability to use the methods of reducing the level of uncertainty for project characteristics 
b) uncertainty qualification means an assessment of the value of each indicator of a web project in terms of existence, accessibility, completeness, accuracy, reliability and durability;

c) in the case where the value of a certain characteristic does not meet these requirements, the possibility of obtaining the value must be determined, and in this case, when this is not possible, the value can be re-install;

d) if the new value of the project characteristic obtained after re-installation is completed, it is included in the final set of decision factors for the choice of project management strategy;

e) if the value obtained requires further correction due to its uncertainty, the process returns to point a);

f) if it is not possible to obtain the value of a specific characteristic of a web project, the necessity and importance of this indicator in the process of choosing a strategy for web project management is assessed (in the case where this value is not critical, ie its influence on the choice of project management strategy is not significant and can be ignored; value removed from use in management strategy selection process (ignored));

g) removal of the value of a specific project factor includes changes in the process of choosing a web project management strategy and further formation of an incomplete set of values of project elements, which are decision-making factors during the implementation of the web project;

h) if the value of this indicator is critical, ie its influence on the decision on the choice of management strategy is significant, determine another possibility to specify it (where possible, these measures form the full value of the relevant indicator of the web project and are included in the final set of decision factors);

i) if it is impossible to further clarify (accept) the critical value of the project indicator, the possibility of obtaining an indefinite linguistic comparison (classification) is determined;

j) if such measures are possible, an ambiguous linguistic assessment of the relevant characteristics of the project is established in accordance with the rules and procedures, this value is a verbal analogue of the relevant indicator, which is interpreted as its value in the alternative scale; k) after receiving the linguistic value of the relevant characteristics of the web project, the inverse transformation should be performed (the result is the numerical value of the linguistic assessment, which can be used in the decision-making process when choosing a project management strategy);

1) the values of the obtained project indicators as a result of the previous stages are included in the set of project characteristics, which are factors in deciding on the choice of management strategy for a particular web project;

$\mathrm{m})$ if it is not possible to obtain the value of the critical project indicator by clarification and classification, it is impossible to make a decision on the project.

\section{Conclusions}

The process of managing a commercial web project, the quality and effectiveness of its results directly depends on the project decisions that are made during its implementation. The content of decisions is influenced by a number of indicators of both the project and its environment. A typical phenomenon for web projects is a situation when the values of project indicators for various reasons are missing, unreliable or inaccurate. In this case, the application of standard design decisionmaking procedures becomes difficult or impossible. One way to solve this problem is to use adequate substitutes instead of real values. This makes it possible to move from the absolute values of the design indicators to the relative estimated characteristics, as well as to replace the missing and inaccurate values. The method of fasification using linguistic meanings was the basis. Bringing fuzzy linguistic estimates to a single numerical scale makes it possible to create a single presentation system for diverse data. The decision-making procedures are modified accordingly, taking into account changes in the system of measuring design characteristics. The practical application of the described approach shows that the quality of decisions made by such a procedure is quite sufficient for the organization of web project management.

\section{References}

1. Berko, A. YU. (2009). Systemy elektronnoyi kontent-komertsiyi [Electronic content commerce systems]. L'viv: Vyd-vo Nats. un-tu «L'vivs'ka politekhnika» [in Ukrainian].

2. Lande, D. Furashev, V., Braychevskiy, S., Grigor'yev, O. (2006). Osnovy modelirovaniya i otsenki yelektronnykh informatsionnykh potokov [Fundamentals of modeling and evaluation of electronic information flows]. Kiîv: Ínzhiníring [in Russian].

3. Lande, D. (2006). Osnovy integratsii informatsionnykh potokov [Fundamentals of information flow integration]. Kiîv: Ínzhiníring [in Russian].

4. Scalable Data Quality: A Seven Step Plan For Any Size Organization (2007). Melissadata Inc. White Papers. Retrieved from http://www.melissadata.com/dqt/whitepaper/scalable-data-quality-whitepaper.pdf.

5. Howell, G., Laufer, A., Ballard, G. (1993). Uncertainty and project objectives. Project Appraisal, 1, 37-43 (Vol. 8).

6. Deyt, K. Dzh. (2005). Vvedeniye v sistemy baz dannykh [Introduction to Database Systems] (12nd ed., Trans). Moskva: Izdatel'skiy dom «Vil'yams» [in Russian].

7. Zadeh, L. A. (1965). Fuzzy sets. Information and control, 8, 338-353 (Vol. 3).

8. Osgood, C. E. (1992). The nature and measurement of meaning. Psychological bulletin, 3, 197 (Vol. 49).

9. Chandrasekaran, S., Golub, G., Gu, M., Sayed, A. (1998). Parameter estimation in the presence of bounded data uncertainties. SIAM Journal on Matrix Analysis and Applications, 1, 235-252 (Vol. 19).

10. Zade, L. A. (2001). Rol' myagkikh vychisleniy i nechetkoy logiki v ponimanii, konstruirovanii i razvitii informatsionnykh / intellektual'nykh sistem [The role of soft computing and fuzzy logic in understanding, design and development of information / intelligent systems] (Trans). Novosti Iskusstvennogo Intellekta, 2 (3), 7-11 [in Russian]. 